\title{
Extraterritoriality and Legal Belonging in the Nineteenth-Century Mediterranean
}

\section{JESSICA M. MARGLIN}

In 1864, Joseph Zédéan died in his native Istanbul. The Greek consulate oversaw Zédéan's estate, claiming him as a Greek subject; according to treaties signed between the Sublime Porte and Greece, Greek nationals were under the jurisdiction of their consulate for matters like inheritance. At first, Zédéan's widow and some other relatives peaceably shared the tutorship over Zédéan's minor children. But before long, the widow accused the relatives of having mismanaged her late husband's fortune. She went to the Greek consulate in Istanbul, asking the consul to revoke these relatives' mandate as tutors of her children. The relatives, in turn, went to the local Ottoman authorities; they claimed that Zédéan had never been a Greek subject, and asked the authorities to seize the estate. After a lengthy exchange with the Greek consulate, Aali Pacha, the Ottoman Minister of Foreign Affairs, wrote an exasperated letter explaining why he could not recognize Zédéan as Greek: "The Imperial Government will not admit that an Ottoman subject may, after a short stay abroad, obtain naturalization in order to undo his previous nationality upon return to his native land, and thus to escape the jurisdiction of his legitimate authority." For Aali Pacha, it was imperative to claim Zédéan as an Ottoman subject; otherwise, anyone could just move to Greece, naturalize as a Greek citizen, and then return to live in the Ottoman Empire as

1. Başbakanlık Osmanlı Arşivi (Istanbul, Turkey: hereafter BOA), HR.HK.318/3, 29 April 1865, Aali Pacha to Delyanni (Legation de Grèce).

Jessica M. Marglin is associate professor of religion, law, and history and Ruth Ziegler Early Career Chair in Jewish Studies, University of Southern California $<$ marglin@usc.edu>. The author thanks the following individuals for their insightful comments on earlier drafts of this article: Kimberly Arkin, Lauren Benton, Naor Ben-Yehoyada, Fahad Bishara, Lia Brozgal, Sam Erman, Ariela Gross, Olivia Harrison, Daniel Hershenzon, Neetu Khanna, Dan Klerman, David Myers, Derek Penslar, Nathan Perl-Rosenthal, Hilary Schor, and the anonymous reviewers for Law and History Review. 
a foreigner, which would cause a blow to the Ottoman Sultan's ability to govern his subjects. The future of Zédéan's inheritance depended on the state to which he belonged: was he a Greek subject when he died, as the Greek consulate claimed? Or was he Ottoman, as Aali Pacha insisted?

Sixteen years later, an attempt was made on the life of 'Abdallah Shamīla (Chemila) at his home in Zliten, in the Ottoman province of Tripolitania (present-day Libya). Fortunately for Shamīla, he was not at home; the assassins instead murdered his servant in broad daylight. Fearing for his life, Shamila went to the local Ottoman authorities, but they failed to investigate or arrest the murderers. So Shamila decamped to Tripoli, where he sought the help of the French consul, Laurent-Charles Féraud. He had already visited the French consulate to deposit an affidavit attesting his birthplace in Mostaganem, in the west of Algeria; as an Algerian, Shamīla was entitled to French diplomatic protection abroad. Shamīla asked Féraud to intervene with the Ottoman authorities and force them to investigate the crime. Féraud was used to this kind of request; French consuls across the Middle East and North Africa regularly made demands on behalf of French citizens from the metropole and colonial subjects from Algeria. But the Ottoman governor was unmoved. He insisted that Shamila was not Algerian, but rather an Ottoman subject falsely claiming Algerian origins. As an Ottoman subject, Shamīla must appeal directly to the Ottoman authorities "in conformity with the law." The Ottoman minister of foreign affairs agreed, insisting that Shamīla was a native of Zliten; the French consul had no right to intervene on his behalf. ${ }^{2}$ Was Shamila an Algerian, and thus entitled to Féraud's intervention? Or was he a subject of the Sublime Porte, and thus limited to making his case before the local Ottoman officials?

$* * *$

The cases of Zédéan and Shamīla both concern the extraterritorial privileges accorded to European subjects in the Ottoman Empire. These extraterritorial privileges stemmed from the capitulations: a series of unilateral concessions first granted by Ottoman sultans to Italian city-states in the medieval period, and gradually expanded to other states in Europe and the Americas. ${ }^{3}$ Thanks to these capitulations, foreigners in the Ottoman

2. BOA, HR.HK.432/5.1, April 7, 1881, Charles Tissot to Assim Pacha; 3, July 28, 1881, Assim Pacha to Tissot; 5, November 8, 1881, Tissot to Assim Pacha.

3. The term "capitulations" is derived from the treaties being organized into chapters, or "capituli." See especially Jacques Lafon, "Les capitulations ottomanes : un droit paracolonial?" Droits: Revue française de théorie, de philosophie et de culture juridiques 28 (1999): 155-80; Edhem Eldem, "Capitulations and Western Trade," in The Cambridge 
Empire could largely escape the jurisdiction of local authorities: they were exempt from local taxation and military service, could rely on their consular officials to intervene on their behalf with the local government, and were partly under the jurisdiction of consular courts. At the beginning of the seventeenth century, the Bey of Tunis - technically an Ottoman functionary, but increasingly asserting partial autonomy from Istanbulbegan to sign his own capitulations with European states. ${ }^{4}$ In the following century, the sultans of Morocco started to do the same. ${ }^{5}$ By 1800 , the subjects of foreign powers could take advantage of extraterritorial privileges from Tangier in the west to Baghdad in the east, and from the Sahara in the south to Belgrade in the north.

The regime of extraterritoriality offers the backdrop for the Greek consulate's claim of authority over Zédéan's estate, and for the French consul's assertion that he had the right to demand justice on behalf of Shamila. In the disputes over Zédéan's estate and the attempt on

History of Turkey, ed. Suraiya Faroqhi (Cambridge: Cambridge University Press, 2006), 289-90; and Fariba Zarinebaf, Mediterranean Encounters: Trade and Pluralism in Early Modern Galata (Berkeley: University of California Press, 2018), ch. 3; on the medieval origins of the capitulations, see esp. 96-105. The literature on extraterritoriality in the Middle East is relatively robust, but see especially Maurits H. Van Den Boogert, The Capitulations and the Ottoman Legal System; Qadis, Consuls, and Beratls in the 18th Century (Leiden: Brill, 2005); Sarah Abrevaya Stein, Extraterritorial Dreams: Jews, Citizenship, and the Calamitous Twentieth Century (Chicago: The University of Chicago Press, 2016); Lâle Can, "The Protection Question: Central Asians and Extraterritoriality in the Late Ottoman Empire," International Journal of Middle East Studies 48 (2016): 67999; Lâle Can, Spiritual Subjects: Central Asian Pilgrims and the Ottoman Hajj at the End of Empire (Stanford, CA: Stanford University Press, 2020), ch. 3; Will Hanley, Identifying with Nationality: Europeans, Ottomans, and Egyptians in Alexandria (New York: Columbia University Press, 2017); and Shana Minkin, Imperial Bodies: Empire and Death in Alexandria, Egypt (Stanford, CA: Stanford University Press, 2019). See also Lâle Can and Michael Christopher Low, "The 'Subjects' of Ottoman International Law," Journal of the Ottoman and Turkish Studies Association 3 (2016): 223-34; Faiz Ahmed, "Contested Subjects: Ottoman and British Jurisdictional Quarrels in re Afghans and Indian Muslims," Journal of the Ottoman and Turkish Studies Association 3 (2016): 325-46; and Michael Christopher Low, "Unfurling the Flag of Extraterritoriality: Autonomy, Foreign Muslims, and the Capitulations in the Ottoman Hijaz," Journal of the Ottoman and Turkish Studies Association 3 (2016): 299-323. On extraterritoriality in law more broadly, see Daniel S. Margolies, Umut Özsu, Maïa Pal, and Ntina Tzouvala, eds., The Extraterritoriality of Law: History, Theory, Politics (London: Routledge, 2019).

4. Ignaz De Testa, Recueil des traités de la Porte Ottomane avec les puissances étrangères, vol. 1 (Paris: Amyot, 1864), 321. For the purposes of this article, I treat Tunisia as a semi-independent polity despite its formal status as an Ottoman province.

5. Mohammed Kenbib, Les protégés : contribution à l'histoire contemporaine du Maroc (Rabat: Faculté des lettres et des sciences humaines, 1996). 
Shamīla's life, it was not clear whether these individuals were, in fact, entitled to the extraterritorial privileges claimed on their behalf. And in both instances, Ottoman authorities resisted granting foreign consulates jurisdiction.

These two cases - like countless others preserved in multiple archivesoffer examples of how claiming extraterritoriality depended on proving one's status as a foreigner. In more abstract terms, extraterritorial privileges were only granted to those who could demonstrate a formal bond linking them to a foreign state. Historians tend to refer to this type of bond with terms like "citizenship," "nationality," or "subjecthood." But these familiar locutions fail us in trying to understand the ways in which state membership and extraterritoriality intersected in the nineteenth-century Mediterranean. To capture the multiplicity and instability of state membership, I introduce the phrase "legal belonging": a neutral, umbrella term that encompasses a wide range of formal bonds between individuals and states.

As the cases of Zédéan and Shamīla suggest, nationality-like other types of legal belonging - was entangled with extraterritoriality in both European empires and Muslim-ruled states. ${ }^{6}$ The connections between citizenship/nationality and extraterritoriality have been noted in a variety of contexts, from Uruguay to Alexandria to Shanghai. ${ }^{7}$ This article investigates how legal belonging evolved in an extraterritorial context across the Mediterranean, adopting the methodology of global legal history at a trans-regional scale. ${ }^{8}$ This perspective requires readers' indulgence as I

6. On "entanglement"-sometimes called histoire croisée or connected history—see especially Michael Werner and Bénédicte Zimmermann, "Beyond Comparison: Histoire Croisée and the Challenge of Reflexivity," History and Theory 45 (2006): 30-50. On the concept in global legal history, see Thomas Duve, ed., Entanglements in Legal History: Conceptual Approaches (Frankfurt am Main: Max Planck Institute for European Legal History, 2014).

7. In a less-cited chapter of her classic book Law and Colonial Cultures, Lauren Benton argues that in nineteenth-century Uruguay, even weak claims to extraterritoriality were crucial in the development of Uruguyan citizenship laws: Lauren Benton, Law and Colonial Cultures: Legal Regimes in World History, 1400-1900 (Cambridge: Cambridge University Press, 2002), ch. 6. Sarah Abrevaya Stein traces Ottoman Jews' pursuit of "protection" in the early twentieth century, arguing that "extraterritoriality undermined regnant citizenship norms in Europe" (Stein, Extraterritorial Dreams, 8). And Will Hanley's study of Alexandria has shown that extraterritoriality was crucial in the development of both the bureaucratic administration of nationality laws, and of ordinary people's identification with nationality as a necessary and ubiquitous form of identity: Hanley, Identifying with Nationality; see also "What Ottoman Nationality Was and Was Not," Journal of the Ottoman and Turkish Studies Association 3 (2016): 277-98.

8. The Mediterranean was one of the original sites of the trans-regional approach that characterizes global history (see especially Henri Pirenne, Mahomet et Charlemagne [Paris: Félix Alcan, 1937]; Fernand Braudel, La Méditerranée et le monde méditerranéen à l'époque de Philippe II [Paris: Colin, 1949]). Yet it has not been on the forefront of the 
switch between political, social, and cultural contexts. But the view from 40,000 feet makes it worth suffering a certain amount of whiplash: it allows us to trace the patterns across polities rarely viewed in the same analytical lens, both within the Middle East and North Africa, and between the Middle East and Europe.

This Mediterranean-wide approach has various rewards; in particular, it helps overturn narratives of modernization that still characterize the history of citizenship in the Middle East. ${ }^{9}$ An older understanding of legal history argues that much of modern law, including conceptions of citizenship and nationality, was invented in the West and exported to the rest of the world. ${ }^{10}$ Middle Eastern polities then adopted these legal institutions. In a somewhat extreme version of this narrative, the incomplete secularization

kind of global legal histories undertaken by scholars of the Indian or Atlantic Oceans: see especially Benton, Law and Colonial Cultures; and A Search for Sovereignty: Law and Geography in European Empires, 1400-1900 (Cambridge: Cambridge University Press, 2010); Fahad Ahmad Bishara, A Sea of Debt: Law and Economic Life in the Western Indian Ocean, 1780-1950 (Cambridge: Cambridge University Press, 2017); see also the articles in the special issue of Law and History Review on "The Travels of Law: Indian Ocean Itineraries," 32 (2014), especially Engseng Ho, "Afterword: Mobile Law and Thick Transregionalism," Law and History Review 32 (2014): 883-89. On global legal history, see especially Lauren Benton and Adam Clulow, "Legal Encounters and the Origins of Global Law," in The Cambridge World History, Volume 6: The Construction of a Global World, 1400-1800 CE, Part 2: Patterns of Change, ed. Jerry H. Bentley, Sanjay Subrahmanyam, and Merry E. Wiesner-Hanks (Cambridge: Cambridge University Press, 2015), 80-100; Thomas Duve, "Global Legal History: Setting Europe in Perspective," in The Oxford Handbook of European Legal History, ed. Heikki Pihlajamäki, Markus D. Dubber, and Mark Godfrey (Oxford: Oxford University Press, 2018), 114-39; "What is Global Legal History?" Comparative Legal History 8 (2020): 73-115; and Joshua C. Tate, José Reinaldo de Lima Lopes, and Andrés Botero-Bernal, "Global Comparative Legal History: An Introduction," in Global Legal History: A Comparative Law Perspective, ed. Joshua C. Tate, José Reinaldo de Lima Lopes, and Andrés Botero-Bernal (Abingdon, Oxon: Routledge, 2019), 1-17. By global history, I do not mean an approach that covers the entire globe, but rather one that transcends national and regional boundaries (such as Europe and the Middle East): see Francesca Trivellato, "Is There a Future for Italian Microhistory in the Age of Global History?" California Italian Studies 2 (2011): 4. For a good précis of the historiography of global history, see Jeremy Adelman, "What is Global History Now?" Aeon Magazine, March 2, 2017.

9. This is related to Dipesh Chakrabarty's call to "provincialize" Europe by questioning the purely European origins of modern political concepts like citizenship: Dipesh Chakrabarty, Provincializing Europe: Postcolonial Thought and Historical Difference (Princeton: Princeton University Press, 2000), 4.

10. Ali Mezghani, Droit international privé : Etats nouveaux et relations privées internationales ; Système de droit applicable et droit judiciaire international (Tunis: Cérès Productions, 1991), 48; and Claire Beaugrand, "Émergence de la 'nationalité' et institutionnalisation des clivages sociaux au Koweït et au Bahreïn," Chroniques yéménites 14 (2007): 89-107. 
of citizenship explains Muslim states' failure to transcend religious or ethnic differences. ${ }^{11}$ More recently, historians have presented alternatives to a centrifugal approach to modernization. ${ }^{12}$ Building on this scholarship, I argue that the evolution of legal belonging on both sides of the Mediterranean developed in response to the challenges and opportunities presented by extraterritoriality, particularly challenges to Middle Eastern states' ability to assert jurisdiction over their members, and opportunities for Western empires to project their influence abroad. Modern legal belonging - like modernity itself - was constructed in dialogue among multiple actors, both European and non-European. This dialogue was not free from hierarchical power relations; in the nineteenth century, European states unquestionably possessed superior military might, and could thus make demands about extraterritoriality despite objections from Ottoman, Tunisian, and Moroccan officials. Nonetheless, legal change moved in multiple directions, instead of only from Europe to the rest of the world. ${ }^{13}$

11. Kemal Karpat, "Millets and Nationality: The Roots of the Incongruity of Nation and State in the Post-Ottoman Era," in Christians and Jews in the Ottoman Empire: The Functioning of a Plural Society, ed. Benjamin Braude and Bernard Lewis (New York: Holmes and Meier, 1982), 141-69; and "Nation and Nationalism in the Late Ottoman Empire," in Studies on Ottoman Social and Political History: Selected Articles and Essays, ed. Kemal Karpat (Leiden: Brill, 2002), 544-55.

12. See especially Sanjay Subrahmanyam, "Connected Histories: Notes towards a Reconfiguration of Early Modern Eurasia," Modern Asian Studies 31 (1997): 735-62; Chakrabarty, Provincializing Europe; Dror Ze'evi, "Back to Napoleon? Thoughts on the Beginning of the Modern Era in the Middle East," Mediterranean Historical Review 19 (2004): 86-90; and James McDougall, "Modernity in 'Antique Lands': Perspectives from the Western Mediterranean," Journal of the Economic and Social History of the Orient 60 (2017): 9. For a critique of modernization theory in the context of law in the Middle East, see Avi Rubin, Ottoman Nizamiye Courts: Law and Modernity (New York: Palgrave Macmillan, 2011), 2-8. Regarding nationality, M'hamed Oualdi cautions against viewing the Islamic Mediterranean "as a place upon which European legal experiences were transplanted" (M'hamed Oualdi, "La nationalité dans le monde arabe des années 1830 aux années 1960 : négocier les appartenances et le droit," Revue des mondes musulmans et de la Méditerranée 137 [2015]: §5). For examples of an alternative approach to the modernization of law, see Samy Ayoub, "The Mecelle, Sharia, and the Ottoman State: Fashioning and Refashioning of Islamic Law in the Nineteenth and Twentieth Centuries," in Law and Legality in the Ottoman Empire and Republic of Turkey, ed. Kent F. Schull, M. Safa Saraçoğlu, and Robert Zens (Bloomington: Indiana University Press, 2016), 129-55; Khaled Fahmy, In Quest of Justice: Islamic Law and Forensic Medicine in Modern Egypt (Berkeley: University of California Press, 2018).

13. For studies outside the Middle Eastern context that challenge a centrifugal model of legal modernization, see, for example, Allan Greer, Property and Dispossession: Natives, Empires and Land in Early Modern North America (Cambridge: Cambridge University Press, 2017); Fei-Hsien Wang, Pirates and Publishers: A Social History of Copyright in Modern China (Princeton: Princeton University Press, 2019). 
I present two case studies to explore the entanglement between extraterritoriality and legal belonging. The first looks at the legislation of legal belonging in the Ottoman Empire, Tunisia, and Morocco: in all three polities, the threat posed by growing numbers of extraterritorial subjects prompted authorities to elaborate the rules of legal belonging. The second turns to the French Empire's approach to categorizing Algerians after the conquest of 1830. I show that extraterritoriality provided the backdrop to understanding the legal belonging of Algerians under French colonial rule, and thus the nature of legal belonging in the French Empire more broadly. Each looks at the regulation of legal belonging both in formal nationality laws and in "infra-legal" texts, including circulars, decrees, treaties, and consular instructions. ${ }^{14}$ Together, the two case studies demonstrate that nineteenth-century legal belonging was constructed in the context of extraterritorial privileges, in Europe and in the Middle East.

A globalized approach to the history of legal belonging is particularly important because nationality law has generally been treated as a quintessentially national endeavor: part of the "reserved domain" that states are free to regulate as they see fit. ${ }^{15}$ In the nineteenth-century Mediterranean, however, the question of who belonged to a particular state had everything to do with the extraterritorial privileges they might or might not claim. Admittedly, a trans-regional lens that flits across the Mediterranean cannot possibly offer a comprehensive account of either extraterritoriality or legal belonging in the nineteenth century. An exhaustive study, however, is not my aim; rather, I hope to suggest the benefits of approaching the entanglement of legal belonging and extraterritoriality on a trans-regional scale - a lens that allows us to see the co-construction of law across political and cultural boundaries.

\section{The Spectrum of Legal Belonging}

I do not eschew more familiar terms like citizenship, nationality, or subjecthood lightly. I do so only because I am convinced that relying on words with such political and cultural specificity-not to mention historical baggage - would ultimately lead to more confusion than clarity. This is why I introduce the umbrella term "legal belonging." I use the term

14. Danièle Lochak, Étranger : de quel droit? (Paris: Presses Universitaires de France, 1987), 205-32; see also Abdellali Hajjat, Les frontières de l' "identité nationale" ; L'injonction à l'assimilation en France métropolitaine et coloniale (Paris: La Découverte, 2012), 59.

15. Christopher Casey, Nationals Abroad: Globalization, Individual Rights, and the Making of Modern International Law (Cambridge: Cambridge University Press, 2020), 61-62. 
"belonging," because it involves both the formal bonds that tie people to a state and forms of membership that stray beyond the strict boundaries imposed by words like "citizen" and "national." I use the term "legal," because it nonetheless concerns ligatures that produce some formal obligation on the part of a state rather than just any sense of connection, whether rooted in identity, territory, or an imagined community of co-nationals. ${ }^{16}$ The state-based dimension of legal belonging is what makes this abstract concept an attribute of sovereignty. ${ }^{17}$

Our conceptualization of citizenship remains colored by the image of "social closure," Rogers Brubaker's evocative phrase; in his scheme, everyone exists on one side of a "conceptually clear, legally consequential, and ideologically charged distinction between citizens and foreigners." 18 Were one to visualize Brubaker's assertions, one might imagine the citizens of given states colored with uniform hues, just like the maps that distinguish the territory of one country from another: the French all blue, Italians all green, Tunisians all red. But legal belonging in the nineteenthcentury Mediterranean was highly fragmented, with different degrees of membership for distinct classes of people. Instead of being a fence between insiders and outsiders, legal belonging encourages us to visualize different types of bonds with a state as existing along a spectrum. ${ }^{19}$

16. On territory, see, for example, Zayde Antrim, Routes and Realms: The Power of Place in the Early Islamic World (Oxford: Oxford University Press, 2012); "imagined community" is, of course, Benedict Anderson's phrase: Benedict Anderson, Imagined Communities: Reflections on the Origin and Spread of Nationalism (London: Verso, 1983). Legal belonging is related to Shana Minkin's discussion of belonging in the context of death in colonial Alexandria (Minkin, Imperial Bodies); legal belonging, however, is a more restricted, precise status than the one Minkin invokes.

17. Compare Marguerite Vanel, "La notion de nationalité : Evolution historique en droit interne et en droit colonial comparé (droit français - droit britannique)," Revue critique de droit international privé 40 (1951): 5. There are robust debates over the concept of sovereignty and whether/how it applies to the Middle East, which I do not have the space to address in this article; by sovereignty, I mean the authority of the ruler or government within a territory (and to some degree beyond that territory, as in the case of extraterritoriality). For a good overview and a helpful bibliography, see Samantha Besson, "Sovereignty," in Max Planck Encyclopedia of Public International Law, ed. Anne Peters and Rüdiger Wolfrum (2011), https://opil.ouplaw.com/view/10.1093/law:epil/9780199231690/law-9780199231690e1472?prd=MPIL (September 4, 2021).

18. Rogers Brubaker, Citizenship and Nationhood in France and Germany (Cambridge, MA: Harvard University Press, 1992), 21. With the characteristic confidence of sociologists, for whom the modern Western nation-state becomes a template to be applied across the globe, Brubaker assures readers that "every modern state" makes such a distinction. For a similarly universalist view of the binary between citizens and foreigners, see Vanel, "La notion de nationalité," 4-5.

19. The idea of seeing citizenship as a spectrum comes from Stein, Extraterritorial Dreams, 9. In addition to Stein's work, see Nancy Cott's study of women and citizenship 
Envisioning legal belonging along a spectrum better captures the ways in which the precise definitions of terms like "citizenship" and "nationality" continued to evolve until the late nineteenth century. Today, jurists distinguish between citizenship - which grants individuals the full range of civil and political rights afforded by state membership; and nationalitywhich is a more stripped-down form of membership that does not presume political rights. ${ }^{20}$ But this distinction emerged at a particular historical moment. In the early nineteenth century, French jurists used the new term "nationality" interchangeably with "citizenship." 21 Only late in the century did jurists begin to differentiate between the two: in 1879, when George Cogordan published the first monograph devoted to nationality, he explained that only French men from the metropole were full citizens. French women were nationals, but not citizens, because they lacked political rights. By that time, Algerians were similarly only nationals, although as I will explore at length, it took decades to determine that colonial

in the United States, which led her to observe that "citizenship can be delivered in different degrees of permanence or strength" and thus was "not a definitive either/or proposition" (Nancy F. Cott, "Marriage and Women's Citizenship in the United States, 1830-1934," American Historical Review 103 [1998]: 1441-42). Linda Bosniak, an expert in immigration law, has noted that the integration of noncitizens into contemporary American society pushes us toward an understanding of citizenship as divided (although her work is only very slightly historicized): Linda Bosniak, The Citizen and the Alien: Dilemmas of Contemporary Membership (Princeton: Princeton University Press, 2006). Finally, Elizabeth Thompson and Daniel Gorman have similarly noted that within the French and British Empires, notions of imperial or colonial citizenship rested on hierarchies that put indigenous subjects far below white Christians from the metropole: Elizabeth Thompson, Colonial Citizens: Republican Rights, Paternal Privilege, and Gender in French Syria and Lebanon (New York: Columbia University Press, 2000); and Daniel Gorman, Imperial Citizenship: Empire and the Question of Belonging (Manchester: Manchester University Press, 2006).

20. Maximilian Koessler, '“Subject,' 'Citizen,' 'National,' and 'Permanent Allegiance,'” Yale Law Journal 56 (1946): 58-76; Paul Weis, Nationality and Statelessness in International Law (Westport, CT: Hyperion Press, Inc., 1956); and Casey, Nationals Abroad, 5, 50-1.

21. Jean-Jacques Gaspard Foelix, the first French jurist to author a monograph on private international law, used the terms "nationality" and "citizenship" interchangeably: Jean-Jacques Gaspard Foelix, Traité de droit international privé, 2nd ed. (Paris: Joubert, 1847); Jean-Jacques Gaspard Foelix and Charles Demangeat, Traité de droit international privé, 3rd ed., 2 vols. (Paris: Marescq et Dujardin, 1856). On "nationality" as a new term, see Gérard Noiriel, "Socio-histoire d'un concept ; Les usages du mot 'nationalité' au XIXe siècle," Genèses: Sciences sociales et histoire 20 (1995): 4-23; Dieter Gosewinkel, "Citizenship, Subjecthood, Nationality: Concepts of Belonging in the Age of Modern Nation States," in European Citizenship: Between National Legacies and Postnational Projects, ed. K. Eder and B. Giesen (Oxford: Oxford University Press, 2003), 17-35. 
subjects in Algeria possessed French nationality. ${ }^{22}$ It is tempting to paper over these uncertainties by projecting the clarity of the twentieth century onto the nineteenth. This is why a more neutral phrase like "legal belonging" can be useful; it better reflects the terminology's instability.

The spectrum of legal belonging proves particularly helpful when accounting for extraterritorial privileges in North Africa and the Middle East. Consular protection allowed local subjects to acquire most of the trappings of extraterritoriality without changing their formal allegiance. Known as himāya in Arabic (or as a berat in Ottoman, the administrative language of the Ottoman Empire), patents of consular protection were originally intended for local subjects in the employ of foreign consulates; eventually, anyone with the requisite resources or wit could acquire protection. ${ }^{23}$ Consular protégés were under the jurisdiction of their protecting power for most matters, yet never formally changed their state membership; they remained subjects of the Ottoman Sultan, the Bey of Tunis, or the Sultan of Morocco. Thus a Tunisian with French consular protection belonged both to Tunisia and to France. ${ }^{24}$ To make matters even more complicated, consuls often extended their protection to individuals with no formal claim on extraterritoriality. ${ }^{25}$ Informal protection may have rested on little more than the caprice of the diplomats involved; but it could prove highly effective in asserting extraterritorial privileges for local subjects.

In short, the proliferation of extraterritorial privileges adds points along our spectrum of belonging. A bit further on from nationality without political rights (women) or civil rights (colonial subjects), we might place those

22. George Cogordan, La nationalité au point de vue des rapports internationaux (Paris: L. Larose, 1879). On the ways in which various groups were excluded from full citizenship, see also Barbara Young Welke, Law and the Borders of Belonging in the Long Nineteenth Century United States (Cambridge: Cambridge University Press, 2010).

23. Increasingly, patents of protection became commodities bought and sold on the black market and entirely disconnected from any actual service in a foreign consulate: Gérard Pélissié du Rausas, Le régime des capitulations dans l'Empire Ottoman, 2 vols. (Paris: Arthur Rousseau, Editeur, 1902-5), 2:33-34; and Van Den Boogert, Capitulations, 76-85.

24. On the ambiguity of the status of consular protégés, see Pélissié du Rausas, Capitulations dans l'Empire Ottoman, 2:42-64. In fact, there was much ambiguity within the category of protection, especially for colonial subjects: on this, see esp. Can, "The Protection Question"; Can, Spiritual Subjects; and Ahmed, "Contested Subjects."

25. See, for example, BOA, HR.HK.427/5.4, April 23, 1865, French Embassy in Istanbul to Sublime Porte. Lauren Benton, Adam Clulow, and Bain Attwood's edited volume on protection focuses on the exercise of sovereignty over territory, rather than over people. Nonetheless, their observations that protection was often vague, informal, and permitted multiple interpretations to co-exist at once all apply to the kind of consular protection described here: Lauren Benton and Adam Clulow, "Introduction: The Long, Strange History of Protection," in Protection and Empire: A Global History, ed. Lauren Benton, Adam Clulow, and Bain Attwood (Cambridge: Cambridge University Press, 2018), 1-9. 
consular protégés who did not formally belong to the protecting state, but nonetheless were under the jurisdiction of the consulate. And at the far end of the spectrum, we find local subjects with no formal claim on state membership or diplomatic protection, who nonetheless managed to invoke the jurisdiction of a consulate. In neither Europe nor the Middle East were the contours of legal belonging singular or fixed; and on both sides of the Mediterranean, these contours were articulated in an extraterritorial context.

\section{Legislating Legal Belonging in North Africa and the Middle East}

The conflict over Joseph Zédéan's estate boiled down to a seemingly simple question: was he an Ottoman subject? Or had he naturalized as a Greek citizen? But as the correspondence in the Ottoman nationality bureau demonstrates, the answer was hardly straightforward. Zédéan's inheritance was disputed in 1864, 5 years before Ottoman authorities attempted to clarify the laws of legal belonging in the Empire. It was precisely cases like Zédéan's - along with many others in which an individual's legal belonging came into question - that prompted the Sublime Porte to issue a decree regulating Ottoman nationality in 1869 . In so doing, the Ottomans were hardly alone: the Bey of Tunis had done the same 8 years earlier, and the Sultan of Morocco did so a decade later. The proliferation of extraterritorial subjects across North Africa and the Middle East prompted these states to regulate legal belonging. The resulting legislation constituted an attempt to stave off the threats posed by the extraterritorial privileges accorded to foreign nationals and protégés.

The number of individuals benefiting from extraterritoriality in the Islamic Mediterranean exploded following the Napoleonic Wars as a result of migration from Southern Europe to the Middle East and North Africa; European colonial expansion, which turned Algerians, Maltese, and Ionians into French and British subjects respectively; and the creation of new nation-states like Greece, to whose citizenship many Ottoman subjects—especially Christians - had easy access. ${ }^{26}$ By the second half of

26. David Todd, "Beneath Sovereignty: Extraterritoriality and Imperial Internationalism in Nineteenth-Century Egypt," Law and History Review 36 (2018): 112-13. On European migration to the Islamic Mediterranean, see: Julia Clancy-Smith, Mediterraneans: North Africa and Europe in an Age of Migration, c. 1800-1900 (Berkeley: University of California Press, 2011); and Hanley, Identifying with Nationality. On the expansion of colonial subjects, see Hanley, ibid., ch. 8. For instances of Ottoman subjects claiming Greek nationality, see, for example, BOA.HR.HK.318/13, Joseph Veli (1893); BOA.HR. HK.318/3, Joseph Simeon Alacaci (1864); BOA.HR.HK.96/5, Thomas Dmitri Zographos (1892); and BOA.HR.HK.94/21, Mihalicli Haci Bosinini (1888). On Greek nationals in 
the nineteenth century, the number of individuals claiming extraterritorial privileges throughout the Islamic Mediterranean had expanded considerably. ${ }^{27}$ The advantages of extraterritoriality were obvious and extensive; foreign nationals and protégés avoided paying local taxes, and thus had a considerable edge when it came to commercial enterprises. They could flout local laws with near impunity, counting on the support of their consulates should they run afoul of the authorities. Many even perfected the art of switching among nationalities or protectors depending on the context, choosing to be Ottoman or Greek, French or Tunisian, according to which affiliation would prove most beneficial under the circumstances. ${ }^{28}$

The extension of extraterritoriality stemmed from a profound imbalance of power that allowed Western polities to insist on compromising the sovereignty of Muslim states. Invocations of extraterritoriality increasingly threatened the authority of local rulers, deducting from their tax revenue, undermining their jurisdiction, and inviting foreign intervention. The

the Ottoman Empire, see Berke Torunoğlu, "The Neo-Hellenes in the Ottoman Empire, 1830-1869," Journal of Modern Greek Studies 39 (2021): 49-70.

27. It is impossible to accurately estimate total numbers of individuals with extraterritorial privileges at any point, since exact counts are almost impossible to come by: Marios Papakyriacou, "Formulation and Definitions of Greek National Ideology in Colonial Egypt (1856-1919)" (PhD diss., Freie Universität Berlin, 2014), 11-12; and Hanley, Identifying with Nationality, ch. 4. Nonetheless, a few examples of this growth are instructive: in 1753, the number of British subjects in the entire Ottoman Empire was around 400 (Ralph Davis, Aleppo and Devonshire Square: English Traders in the Levant in the Eighteenth Century [London: Macmillan, 1967], 61). By 1848, the English vice-consul in Tunis estimated that 5,800 British subjects lived in Tunisia alone. The vast majority were Maltese, who were considered British by virtue of the empire's rule over the island since 1816; 200 more were Ionians (also colonial subjects), and 35 were from the British Isles (Clancy-Smith, Mediterraneans, 40). Similarly, there were 161 French nationals in Tunis in 1816 ("Etat des français en Barbarie," Archives Nationales de France, draft by Anne Mézin, to whom I am deeply grateful for sharing this information). By 1876, estimates put the number of French nationals in Tunisia between 7,000 and 16,600, the vast majority of whom were Algerians (Kamel Kateb, Européens, "indigènes" et juifs en Algérie [18301962]; Représentations et réalités des populations [Paris: Insitut National d'Etudes Démographiques, 2001], 53, see also 50-54, 156-59; 'Abd al-Qarīm Al-Mājirī, Hijra al-jazā'iriȳin wal-tarābulisīya wal-maghāriba al-jawāwina ilā Tūnis [1831-1937] [Tunis: Al-Sharika al-Tūnisīya lil-Nashr wa-Tanmiya Funūn al-Rasm, 2010], 87-96, 129; and Mary Dewhurst Lewis, Divided Rule: Sovereignty and Empire in French Tunisia, 18811938 [Berkeley: University of California Press, 2014], 19).

28. There is considerable research on the motivations for acquiring extraterritorial privileges and the ways in which some individuals navigated among different legal statuses: see especially Ziad Fahmy, "Jurisdictional Borderlands: Extraterritoriality and 'Legal Chameleons' in Precolonial Alexandria, 1840-1870," Comparative Studies in Society and History 55 (2013): 305-29; Stein, Extraterritorial Dreams; Hanley, Identifying with Nationality; and Torunoğlu, "Neo-Hellenes." 
Sultans of Morocco and the Ottoman Empire and the Beys of Tunis were desperate for ways to limit the growing ranks of people with extraterritorial privileges. There was little they could do to curtail the numbers of immigrants; even in Europe and the Americas, borders were almost entirely open. ${ }^{29}$ But they could try to limit the numbers of their own subjects who obtained extraterritorial privileges by acquiring foreign nationality or protection.

The link between extraterritoriality and legal belonging is particularly apparent in the laws that these polities promulgated to determine how one acquired or lost one's status as a member of the state - what came to be known as "nationality legislation." Examining the legislation of legal belonging in the Ottoman Empire, Tunisia, and Morocco reveals that in each case, legal reforms responded directly to the explosion of extraterritoriality.

Tunisia was the first polity in the Islamic Mediterranean to formally legislate legal belonging. The regulation of Tunisian nationality in the 1861 Qānūn al-dawla - usually called the Constitution in Western languagesemerged in large part from of an attempt to control the growth of extraterritoriality. ${ }^{30}$ The Qānūn al-dawla dedicated one article to the acquisition or loss of membership in the Tunisian state: the bread and butter of nationality law: "Every Tunisian (al-tūnisī) who moves to a different state-for whatever reason, whether his absence is long or short, and whether he is counted among the people of the state or not—-becomes a Tunisian subject again upon re-entering Tunisia." ${ }^{31}$ In other words, the Qānūn al-dawla was primarily concerned with the question of losing one's status as a Tunisian national. The law explicitly prohibited Tunisians who naturalized abroad from conserving their foreign nationality once they were back in Tunisia and thus from enjoying the extraterritorial privileges associated with foreign nationality.

Contemporary observers understood this law as a response to the abuse of extraterritorial privileges rife in Tunisia. Pasquale Stanislao Mancini, Italy's most famous scholar of international law, had occasion to comment on this law during a drawn-out legal battle over the estate of a Tunisian Jew named Nissim Shamama. ${ }^{32}$ Mancini explained that the law was intended to

29. Jane Caplan and John Torpey, "Introduction," in Documenting Individual Identity: The Development of State Practices in the Modern World, ed. Jane Caplan and John Torpey (Princeton: Princeton University Press, 2001), 10.

30. Fatma Ben Slimane, "Entre deux empires : l'élaboration de la nationalité tunisienne," in Maghreb et sciences sociales (Tunis: L'Harmattan-IRMC, 2012), especially 111-13.

31. Qānūn al-dawla, ch. 12, art. 7, https://www.justice.gov.tn/fileadmin/medias/ministere/ musee/constitution_1861_ar.pdf (August 4, 2021).

32. On this case, see Abdelhamid Larguèche, "Nasim Shammama ; un caïd face à lui-même et face aux autres," in Juifs et musulmans en Tunisie : fraternité et 
prevent foreign powers from using naturalization as "a pretext for the illegitimate extension of their jurisdiction." ${ }^{33}$ General Husayn b. 'Abdallah, a former slave (mamlük) and a Tunisian government official charged with representing the Bey of Tunis's interests in the Shamama case, agreed; he also explained that the relevant article in the Qānūn al-dawla was written in response to the rampant abuses of extraterritoriality in Tunisia. ${ }^{34}$

Ottoman attempts to regulate nationality responded to similar challenges. Most Ottoman historians have focused on the 1869 nationality law as the first formal regulation of membership in the empire. In fact, a circular issued 6 years earlier-attempting to regulate consular protection - should be seen as the first formal legislation of legal belonging. The circular of 1863 stated that consular protection could no longer extend to family members, be inherited by descendants, or attach to individuals working for individual foreigners (as opposed to foreign consulates). ${ }^{35}$ Moreover, the number of employees eligible for consular protection was strictly limited: four guards and four dragomen (translators) for consulates general; three each for subsidiary consulates; and two each for vice-consulates. ${ }^{36}$ This regulation had the effect of severely limiting the number of individuals who could claim consular protection in the Ottoman Empire. When consular protection is understood as a form of legal belonging, this circular is seen clearly as an attempt to regulate membership in the Ottoman State by limiting the number of Ottoman subjects who could claim foreign protection, and thus extraterritorial privileges.

déchirements, ed. Sonia Fellous (Paris: Somogy éditions d'art, 2003), 143-57; Fatma Ben Slimane, "Définir ce qu'est être Tunisien : litiges autour de la nationalité de Nessim Scemama (1873-1881)," Revue des mondes musulmans et de la Méditerranée 137 (2015): 31-48; and Jessica M. Marglin, "La nationalité en procès : droit international privé et monde méditerranéen," Annales. Histoire, Sciences Sociales 73 (2018): 83-118; see also my book on the subject, forthcoming with Princeton University Press.

33. Pasquale Stanislao Mancini, Corte di appello di Lucca; Per gli eredi testamentari del fu Conte Caid Nissim Samama contro i pretendenti alla sua eredità ab intestato ; Ricerca della legge regolatrice della successione del testatore (Rome: Tipografia Fratelli Pallotta, 1880), 280.

34. Al-Ginirāl Ḥusayn, "Al-qusțās al-mustaqīm fĩ zuhūr ikhtilāl al-ḥukm bi-nafî jinsīyat al-qā'id Nisīm," in Al-ginirāl Husayn : Hayātuhu wa-ātharuhu, ed. Aḥmad al-Ṭawīl̄̄ (Tunis: 1994), 242. On Husayn, see especially M'hamed Oualdi, A Slave Between Empires: A Transimperial History of North Africa (New York: Columbia University Press, 2020).

35. The full text (in French) can be found in Pierre Arminjon, Etrangers et protégés dans l'Empire ottoman (Paris: A. Chevalier-Maresq \& Cie., 1903), 325-30. See also Lafon, "Les capitulations," 179; Yerri Urban, L'indigène dans le droit colonial français, 1865-1955 (Paris: Fondation Varenne, 2010), 74; Hanley, "Ottoman Nationality," 284-85.

36. Article 1 (Arminjon, Étrangers et protégés, 325). 
The problem was that the 1863 circular on consular protection could not dampen individuals' desire to seek out the advantages of extraterritoriality. Once it became extremely difficult to obtain a patent of protection, Ottoman subjects instead turned to foreign naturalization; the circular said nothing about foreign nationals, whose rights to extraterritoriality remained unchanged. This is the context in which the Ottoman nationality law of 1869 was passed. ${ }^{37}$ Scholars writing in the decades following the law's promulgation had no doubt that the law attempted to curb the increase in individuals with extraterritorial privileges. Pierre Arminjon, a French jurist working in Cairo, explained that the nationality law was directly related to the Ottoman edict of 1863 that sought to limit consular protection. ${ }^{38}$ The law of 1869 addressed the new wave of foreign naturalizations by making it harder for Ottomans to denaturalize: "But if [an Ottoman subject] should enter into a foreign nationality without being authorized by the Imperial Ottoman Government, his new nationality shall be considered as null and void, and he shall be considered as an Ottoman subject as before...." ${ }^{39}$ There were undoubtedly other factors weighing on the decision to pass the 1869 legislation: a general impetus toward legal and political reform (usually described as the Tanzimat), and international relations, particularly those with Qajar Persia. ${ }^{40}$ But the main impetus driving the new rules regarding legal belonging was the dramatic increase in the number of individuals benefiting from extraterritoriality.

Unsurprisingly, the Ottoman nationality law did not resolve all questions regarding legal membership in the empire. Subsequent cases involving changes of nationality played out in the competition over jurisdiction between Ottoman authorities and Western states. For instance, a man

37. Hanley, "Ottoman Nationality," 285. See also Abdelouahed Belkeziz, La nationalité dans les états arabes (Rabat: Editions "La Porte," 1963), 8-9; and Gianluca P. Parolin, Citizenship in the Arab World: Kin, Religion, and Nation-State (Amsterdam: Amsterdam University Press, 2009), 73.

38. Arminjon, Étrangers et protégés, 68. On Arminjon, see Will Hanley, "International Lawyers without Public International Law: The Case of Late Ottoman Egypt," Journal of the History of International Law 18 (2016): 108. On this law, see also du Rausas, Capitulations dans l'Empire Ottoman, 2:37-40.

39. Article 5, "Tabiyet uthmaniye kanunnamesinder," Düstur 1289 (1872-73): 16-18. The English translation is from Karen Kern, Imperial Citizen: Marriage and Citizenship in the Ottoman Frontier Provinces of Iraq (Syracuse, NY: Syracuse University Press, 2011), 157-58.

40. See Bruce Masters, "The Treaties of Erzurum (1823 and 1848) and the Changing Status of Iranians in the Ottoman Empire," Iranian Studies 24 (1991): 3-15; Sabri Ateş, The Ottoman-Iranian Borderlands: Making a Boundary, 1843-1914 (Cambridge: Cambridge University Press, 2013), 56, 197-98. 
named Antoine Zelitz - who was originally from Austro-Hungary, but had lived in Istanbul for 30 years - naturalized as an Ottoman in 1872. When the Ottoman Ministry of Foreign Affairs wrote to the Austro-Hungarian Embassy to inform them that Zelitz was no longer entitled to their protection, Count Ludolf, the ambassador, rejected Zelitz's claim to Ottoman nationality. ${ }^{41}$ Ludolf argued that Austro-Hungary required its subjects to request permission from the government before expatriating themselves and acquiring a different nationality, just as the Ottoman nationality law required of Ottoman subjects. ${ }^{42}$ But the Ottoman authorities dug their heels in, insisting that Zelitz was a subject of the Sultan. The prime minister and the minister of foreign affairs argued that it was an attack on Ottoman sovereignty to require approval from a foreign government for the application of Ottoman nationality law. ${ }^{43}$ Zelitz was the rare foreigner who voluntarily opted to give up his extraterritorial privileges, a trend that Ottoman officials wanted to encourage. ${ }^{44}$ The two states remained in deadlock, each insisting that Zelitz legally belonged to them. The Zelitz case reflected challenges posed by the application of nationality law in an extraterritorial context in which Austro-Hungary might still lay a robust claim to jurisdiction over a person that the Ottoman bureaucracy considered to be an Ottoman subject. ${ }^{45}$

Unlike in Tunisia and the Ottoman Empire, authorities in Morocco never formally legislated legal belonging before the colonial period. Nonetheless, the emergence of a category corresponding to Moroccan nationality crystallized in the context of extraterritoriality. Like the Ottoman and Tunisian governments, the Moroccan makhzan (central government) was faced with ever-growing numbers of individuals who claimed extraterritorial privileges as foreigners or as foreign protégés. It was increasingly common for Moroccan subjects to travel abroad, obtain foreign nationality, and then return to Morocco to benefit from extraterritorial privileges. The American jurist Elihu Root noted that in the early twentieth century, half of the American citizens in Morocco were of Moroccan origin, and had returned home after naturalizing in the United States. ${ }^{46}$

41. BOA, HR.HK.380/11.1, August 8, 1872, Rapport du Kitabet du Ministère des Affaires Etrangères.

42. BOA, HR.HK.380/11.2, July 6, 1872, consul of Austro-Hungary in Istanbul to Direction générale des passeports.

43. BOA, HR.HK.380/11.5, September 26, 1872, Grand Vizir to Comte Ludolf; and HR. HK.380/11.8, November 27, 1872, Khalil Pasha to Comte Ludolf.

44. See also BOA, HR.HK.382/6, Nationality of Yusuf Griecker (1878).

45. See also BOA, HR.HK.378/11, Nationality of Sabino Cosulich (1865).

46. Elihu Root, "The Basis of Protection to Citizens Residing Abroad," The American Journal of International Law 4 (1910): 520. 
These abuses of extraterritoriality were thrust into the limelight in 1880 , as a number of Western states prepared for an international conference intended in part to solve these problems. The Moroccan Foreign Minister, Muhammad Bargash, wrote a letter to all the foreign ambassadors in which he lamented "the harm done to the state by those Moroccan subjects (al-ra 'ìya al-Marākshīya) who ask for documents of naturalization (al-nātūurālīzāsiyunn) and then claim that they are outside the rules of the Moroccan government (khārijūn 'an ahkām al-wilāyati al-Marākshīya).,"47 Bargash then quoted a decree from the Sultan, Mawlay Hasan, declaring that henceforth he would "not accept that any of his subjects, Muslim or Jew, exchange his nationality for another one (abdala ra'yyatahu bi-ra 'iyatihi ukhrā). ${ }^{48}$ Bargash's letter was studiously ignored by the foreign ambassadors to whom it was addressed. Nonetheless, his words represent an attempt to regulate and define Moroccan legal belonging in the context of growing numbers of Moroccans claiming extraterritorial privileges.

The Treaty of Madrid, signed the following summer, offered Morocco's first formal regulation of legal belonging. ${ }^{49}$ Mawlay Hasan failed in his attempt to prevent all Moroccan subjects from naturalizing abroad. Nonetheless, the Moroccan delegates at the conference managed to limit the extent to which Moroccans could benefit from extraterritorial privileges after having obtained a foreign nationality. Article 15 declared: "Any subject of Morocco (jamī'u al-ra 'ìyati al-marākushīyati) who has been naturalized (akhadhī al-națuraliziss) in a foreign country, and who shall return to Morocco, shall after having remained for a length of time equal to that which shall have been regularly necessary for him to obtain such naturalization, choose between entire submission to the laws of the Empire and the obligation to quit Morocco...."50 This regulation of Moroccan nationality-like its Tunisian and Ottoman equivalents-focused on those Moroccans who were naturalized abroad, and then returned to Morocco with extraterritorial privileges. In attempting to curb the numbers of Moroccan subjects who acquired extraterritoriality, the Treaty of Madrid took the first steps in defining rules for the legal belonging of Moroccans.

47. Direction des Archives Royales (Rabat, Morocco: hereafter DAR), Ḥimāyāt, 10090, 25 Safar 1297/ February 8, 1880, Bargash to foreign ambassadors.

48. DAR, Ḥimāyāt, 10090, 25 Ṣafar 1297/ February 8, 1880, Bargash to foreign ambassadors.

49. On the Conference of Madrid, see: 'Abd al-Wahhāb Ibn Manșūr, Mushkilat al-himāya al-qunșuliyya bi-'l-Maghrib (Rabat: al-Maṭba'a al-mālikīya, 1985), 77-114; Kenbib, Les protégés, 57-66; and Khalid Ben-Srhir, Britain and Morocco during the Embassy of John Drummond Hay, 1845-1886 (London: RoutledgeCurzon, 2005), 185-92.

50. Article 15: for French and Arabic versions of the treaty, see Ibn Manșūr, Mushkilat al-himāya, 193-208. 
Of course, the existence of laws governing legal belonging in the Ottoman Empire, Tunisia, and Morocco hardly solved the problem of people whose state membership remained a point of contention. The process of determining legal belonging often remained highly personal; it was quite common to resort to local religious leaders - especially rabbis and priests - to establish an individual's status. For instance, when the heirs of Joseph Zédéan contested the nationality of their deceased relative, both Ottoman and Greek diplomats turned to religious leaders. The Greek consulate consulted the registers of the Armenian Catholic church in Büyükdere (a neighborhood of Istanbul), which confirmed that Zédéan died a Greek national. ${ }^{51}$ The Ottoman minister of foreign affairs countered that according to the patriarch of the Armenian Catholic Church in Istanbul, Zédéan belonged to "an old Istanbul family, who is inscribed in the registers under the name of Joseph Siméon," and that Zédéan "never left this city to go abroad." 52 In the absence of even an attempt at a universal identification regime, Ottoman officials resorted to those who already possessed authority within their community to vouch for their constituents.

Ottoman, Tunisian, and Moroccan officials all tried to reign in the explosion of extraterritoriality and its concomitant abuses by defining legal belonging. Because of this, nationality regulations in all three states primarily concerned expatriation - the loss of legal belonging - whereas the attribution or acquisition of legal belonging was either dealt with summarily (as in the Ottoman law) or ignored completely (as in the Tunisian and Moroccan cases). All of these states had to define who legally belonged if they wanted to curb the proliferation of individuals with extraterritorial privileges.

\section{Extraterritoriality and Legal Belonging in the French Colonial Maghrib}

As with the fight over Joseph Zédéan's inheritance, the battle for jurisdiction over 'Abdallah Shamīla boiled down to his legal belonging. Was Shamīla of Algerian origin, and thus a French national? Or was he a local Tripolitanian posing as an Algerian, hoping thereby to illegally benefit from extraterritoriality? Were he to prove his Algerian origins, Shamīla's status as a French national would have been clear. But the designation of Algerians as possessing French nationality had only been legislated in 1865; before that, the precise status of Algerians-both inside

51. BOA, HR.HK.318/3, February 9, 1864, Delyanni to Aali Pacha.

52. BOA, HR.HK.318/3, March 22, 1865, Aali Pacha to Delyanni. 
and outside of Algeria - was very much up for debate. Ultimately, the decision to consider Algerians like Shamīla as French nationals was made in large part with extraterritoriality in mind.

The extraterritorial context of determining Algerians' legal belonging demonstrates that Muslim-ruled states were not the only polities in the Mediterranean who shaped their nationality law in response to the capitulations. In metropolitan Europe, nationality legislation was primarily informed by pressing issues in the metropole, particularly immigration, military services, political rights, and, especially for "sending" countries like Italy, emigration. ${ }^{53}$ But the promise of extraterritorial privileges for colonial subjects was crucial to shaping legal belonging in European empires. The status of Algerians outside of Algeria - under French rule since 1830 - offers a particularly good example of how extraterritoriality shaped imperial legal belonging.

Algerians were eligible for French protection when they traveled outside of Algeria, meaning that they enjoyed more or less the same kinds of extraterritorial privileges granted to French nationals from the metropole. Yet it took decades for French jurists and legislators to determine the precise legal status of Algerians. This is another instance in which the spectrum of legal belonging helps to clarify a history often obscured in the scholarly literature. ${ }^{54}$ Algerians under French protection were not citizens, nor were they consular protégés; yet they belonged to France, often in ways that French officials themselves argued over. When French jurists and legislators finally clarified the condition of Algerians - determining that they were French nationals, but not citizens (unless they had naturalized as such) - they based their decision in large part on the protection enjoyed by Algerians outside of Algeria.

53. See, for example, Patrick Weil, Qu'est-ce qu'un Français ? : Histoire de la nationalité française depuis la Révolution (Paris: Gallimard, 2002); Gérard Légier, Histoire du droit de la nationalité française des origines à la veille de la réforme de 1889 (Aix-en-Provence: Presses universitaires d'Aix-Marseille, 2014); Nancy L. Green and François Weil, "Introduction," in Citizenship and those who Leave: The Politics of Emigration and Expatriation, ed. Nancy L. Green and François Weil (Urbana: University of Illinois Press, 2007), 1-9; and Donna R. Gabbacia, Dirk Hoerder, and Adam Walaszek, "Emigration and Nation Building during the Mass Migrations from Europe," in Citizenship and those who Leave: The Politics of Emigration and Expatriation, ed. Nancy L. Green and François Weil (Urbana: University of Illinois Press, 2007), 63-90. Recently, Christopher Casey has explored the ways in which nationality and international law in the West were shaped by migration and a state's duty to protect its nationals abroad (Casey, Nationals Abroad, chs. 1-2). In a relatively brief discussion of colonial and extraterritorial contexts, he argues that the status of colonial subjects was often determined outside of the empire in question (at 62-65); his discussion of Algerians (at 64) offers a good précis of the situation, although he only begins in 1865 .

54. For instance, Patrick Weil claims that Algerians had French nationality starting in 1830: Weil, Qu'est-ce qu'un Français ?, 339-41. 
Scholarship on the question of legal belonging in Algeria has been premised on a dichotomy of citizen versus subject. Historians have focused on the denial of full citizenship to Algerians, who were barred from political rights and thus from full membership in the French state. ${ }^{55}$ Many have also written on the granting of citizenship to Jews by the Crémieux decree of $1870 .^{56}$ And post-colonial historians in particular have noted the ways in which citizenship regimes shaped decolonization, and vice versa. ${ }^{57}$ But the influence of extraterritoriality on the legal belonging of Algerians has yet to be fully explored and constitutes an important example of how nationality laws in the French Empire responded to the promises and perils of the capitulations. ${ }^{58}$

Immediately after colonization began, French authorities encountered questions about the status of Algerians living elsewhere in the Mediterranean. French forces descended on Algiers on July 5, 1830. That same month, a Jew claiming Algerian origins requested protection from the French consulate in Smyrna (Izmir); he wanted to benefit from the extraterritorial privileges granted to Europeans, now that his homeland

55. Laure Blévis, "Les avatars de la citoyenneté en Algérie coloniale ou les paradoxes d'une catégorisation," Droit et société 48 (2001): 557-81; "L'invention de 1'“indigène', Français non citoyen," in Histoire de l'Algérie à la période coloniale, 1830-1962, ed. Abderrahmane Bouchène, Jean-Pierre Peyroulou, Ouanassa Siari Tengour, and Sylvie Thénault (Paris: La Découverte, 2012), 212-18 and "Quelle citoyenneté pour les Algériens?" in Histoire de l'Algérie à la période coloniale, 1830-1962, ed. Abderrahmane Bouchène, Jean-Pierre Peyroulou, Ouanassa Siari Tengour, and Sylvie Thénault (Paris: La Découverte, 2012), 352-58; Olivier Le Cour Grandmaison, De l'indigénat ; Anatomie d'un "monstre" juridique : le droit colonial en Algérie et dans l'Empire français (Paris: La Découverte, 2010); and Yerri Urban, "La citoyenneté dans l'empire colonial français est-elle spécifique ?" Jus Politicum 14 (2015): 1-34.

56. See, for example, Benjamin Stora, Les trois exils ; Juifs d'Algérie (Paris: Editions Stock, 2006); and Sophie Roberts, Citizenship and Antisemitism in French Colonial Algeria, 1870-1962 (Cambridge: Cambridge University Press, 2017).

57. See especially Todd Shepard, The Invention of Decolonization: The Algerian War and the Remaking of France (Ithaca, NY: Cornell University Press, 2006); and Frederick Cooper, Citizenship between Empire and Nation: Remaking France and French Africa, 1945-1960 (Princeton: Princeton University Press, 2014).

58. The partial exception is the work of Noureddine Amara, who explores questions of nationality in his study of Algerians outside of Algeria: see especially Noureddine Amara, "Les nationalités d'Amîna Hanım ; Une pétition d'hérédité à la France (1896-1830)," Revue des mondes musulmans et de la Méditerranée 137 (2015): 49-72; see also "Être algérien en situation impériale, fin XIXème siècle - début XXème siècle: L'usage de la catégorie 'nationalité algérienne' par les consulats français dans leur relation avec les Algériens fixes au Maroc et dans l'Empire Ottoman," European Review of History 19 (2012): 59-74; "Faire la France en Algérie : émigration algérienne, mésusages du nom et conflits de nationalités dans le monde. De la chute d'Alger aux années 1930" (PhD diss., Université Paris I Panthéon-Sorbonne, 2019). 
was under French rule. On August 2, the local consul wrote to his superiors at the Ministry of Foreign Affairs asking for instructions. ${ }^{59}$ Increasing numbers of similar cases prompted the Ministry of Foreign Affairs to issue a circular in 1834, 5 months before the formal annexation of Algeria. The circular determined which Algerians abroad were eligible for French protection. Those who had left Algeria and intended to return (that is, who conserved an "esprit de retour") "have retained their quality of an Algerian (qualité d'algérien) and thus are able to invoke the protection of His Majesty's agents." ${ }^{60}$ This circular offered clear instructions to French diplomats: they had a duty to extend extraterritorial privileges to those determined to still have the "quality of an Algerian." 61

But affirming Algerians' right to French protection abroad hardly settled the matter of their nationality. The 1834 circular attached Algerians to French sovereignty, affirming that in some way, possessing the "quality of an Algerian" meant that they belonged to France. But how to define this belonging, and its precise contours, remained unclear. Nor were French imperial authorities alone in both extending protection to Algerians, and refraining from defining their status. The British government similarly asserted its jurisdiction over colonial subjects both inside and outside their Empire, without precisely saying what this meant. ${ }^{62}$

The policy of extending protection to Algerians abroad was controversial in French political circles. Officials in Paris worried about angering the Ottoman government by declaring thousands of Muslims living in Ottoman territory to be French subjects more or less overnight. But those with an eye to expanding France's Mediterranean empire realized that more people under French protection would translate into increased French influence. ${ }^{63}$ And conveniently, the ad hoc way in which individuals

59. Rina Cohen, "Les juifs 'Moghrabi' en Palestine (1830-1903) : Les enjeux de la protection française," Archives Juives 38 (2005): 28-29; pace Urban, L'indigène dans le droit colonial, 48. On Jews from North Africa who moved to Palestine in the nineteenth century, see Michal Ben Ya'akov, "The Montefiore Census and Research on Jews in the Mediterranean Basin [Hebrew]," Pe'amim 107 (2006): 140-45.

60. Circular of April 31, 1834, cited in Cohen, "Les juifs 'Moghrabi' en Palestine," 29.

61. See also Al-Mājirī, Hijra al-jazā'iriyinn, 351-3; and Anne-Marie Planel, "Les ressortissants de la protection consulaire française en pays musulman," Mélanges de la Casa de Velázquez 51 (2021).

62. See, for example, Lisa Ford, Settler Sovereignty: Jurisdiction and Indigenous People in America and Australia, 1788-1836 (Cambridge, MA: Harvard University Press, 2010); Hannah Weiss Muller, Subjects and Sovereign: Bonds of Belonging in the Eighteenth-Century British Empire (Oxford: Oxford University Press, 2017), chs. 3-5.

63. Urban, L'indigène dans le droit colonial, 52; Amara, "Être algérien en situation impériale," 64-66. French officials were often opposed to allowing Algerians to naturalize as Tunisians or Ottomans: Kateb, Européens, "indigènes" et juifs en Algérie, 162-64. 
were to prove their qualité d'algérien - and thus qualify for French protection-left French authorities a lot of wiggle room in deciding just how much or little to expand their influence in a particular place. According to the 1834 circular, Algerians who left after 1830 should have obtained a passport from the French authorities to travel outside the empire; this would serve as evidence of their status. As for the many who had left Algeria before 1830, "in the absence of fixed rules, which the customs of the Orient make it impossible to identify precisely, I can only entrust the consuls of [France] to form their opinions according to the circumstances of fact and place." ${ }^{64}$ In other words, the practices regulating Algerians' status gave French consuls considerable room for maneuver. Although Algerians were technically required to register at their local French consulate each year to maintain their entitlement to protection, consuls had much leeway in determining who was and was not Algerian. ${ }^{65}$ This meant that French diplomats could expand or contract the number of Algerians benefiting from French protection depending on their interests.

France often used the extraterritorial privileges of its Algerian subjects as an excuse to meddle in the internal affairs of foreign polities. For instance, in 1865, the French consul in Tunis sent a French warship to the port of La Goulette following incidents in which Algerians had been made to pay taxes or were corporally punished by Tunisian officials. He gave the Bey 24 hours to give him "satisfaction," which in this context meant compensation and assurances that such incidents would not be repeated. ${ }^{66}$ In 1895, the French consuls in Safed and Beirut tried to convince a group of Algerians who had settled in the region to register with the French consulate. This was a way of increasing the number of people under their protection, and thus their influence - particularly desirable in the sensitive province of Palestine, where Safed was located. ${ }^{67}$

Ottoman officials naturally resented these sorts of demands. They made a concerted effort to limit French influence on their internal affairs by

64. Cohen, "Les juifs 'Moghrabi' en Palestine," 29.

65. See, for example, Centre d'Archives Diplomatiques de Nantes (Nantes, France: hereafter CADN), 1TU/500/85, Registre d'immatriculation des israélites algériens, 1869-76; the “justification" given as proof of Jews' Algerian descent varied greatly, from a single passport, to affidavits drawn up in Algeria, to documents in Hebrew and/or Judeo-Arabic signed by local Tunisian rabbis. See also Planel, "Les ressortissants de la protection consulaire française en pays musulman,” especially §27.

66. Jean Ganiage, Les origines du protectorat Français en Tunisie (1861-1881), 2nd ed. (Tunis: Maison Tunisienne de 1'Edition, 1968), 239-40.

67. BOA, Y.PRK.MYD, 16/79, 30 Muharrem 1313/ July 23, 1895, Muhammed bin Abdülkadir and Muhiddin bin Abdülkadir to ? (in Yusuf Sarinay, ed., Osmanll belgelerinde Cezayir [Ankara: Grafik-Tasarım-Bask1, 2010], 328-29). 
forcing Algerians to naturalize as Ottoman subjects. ${ }^{68}$ And as we saw in the case of Shamīla, Ottoman authorities often refused to recognize certain individuals as Algerians, claiming that they were Ottoman subjects who had merely lied about their origins to acquire extraterritorial privileges. ${ }^{69}$ Yet as frustrating as these privileges proved for Ottoman officials, French protection was a two-way street; individuals claiming Algerian status could manipulate the political circumstances to their advantage. In the decades after French conquest, many of the Algerians who left Algeriaincluding those who sought to escape colonial rule - successfully claimed extraterritorial privileges in French consulates across the Ottoman Empire, Tunisia, and Morocco. ${ }^{70}$

Still, the legal belonging of Algerians remained unclear, both within and outside of French territory. Their status came up in the writings of reformers such as Ismail Urbain, among the most famous Saint-Simonians whose ideas greatly influenced French policy in Algeria. Urbain believed that Algerians should be offered a clear path toward assimilation to France and, eventually, French citizenship. His argument rested in part on the fact that "concerning nationality, natives (indigènes) must be French. Once they travel abroad, France's political protection follows them everywhere, and they know how to take advantage of it." ${ }^{71}$ According to Urbain, French authorities had determined the de facto nationality of Algerians through diplomatic practice, if not yet through legislation.

It was not until the 1860s that French jurists defined the legal belonging of Algerians. A case concerning Élie-Léon Enos, an Algerian Jewish lawyer who asked to be admitted to the bar in Algiers, first forced French courts to adjudicate the nationality of Algerians. ${ }^{72}$ The Algiers bar refused

68. See, for example, BOA, Y.A.RES, 49/39, no date (probably 22 Rebi'u'l-evvel 1307/ November 16, 1889), Yıldız Saray-1 Hümayunu, Başkitabet dairesi; BOA, BEO, 26103, 18 Receb 1311/ January 25, 1894, Hariciye Nezaret-i Celilesi'ne; BOA, MV.145/21, 19 Șevval 1328/ October 24, 1910, Meclis-i Vükelâ Müzâkerâtına Mahsûs Zabıt Varakasıdır (in Sarinay, Osmanl belgelerinde Cezayir, \#66, \#71, \#75).

69. See also BOA.HR.HK.430/7, Bilalaki Yakub Efendi (1874).

70. See especially Jessica M. Marglin, "The Two Lives of Mas'ud Amoyal: Pseudo-Algerians in Morocco, 1830-1912," International Journal of Middle East Studies 44 (2012): 651-70; and Amara, "Faire la France en Algérie."

71. Ismayl Urbain, L'Algérie pour les algériens (Paris: Michel Lévy Frères, 1861), 129-30. See also L'Algérie française ; indigènes et immigrants (Paris: Challamel Ainé, 1862), 5. On Saint-Simonians in Algeria see Osama Abi-Mershed, Apostles of Modernity: Saint-Simonians and the Civilizing Mission in Algeria (Stanford, CA: Stanford University Press, 2010).

72. Urban, L'indigène dans le droit colonial, 76-85; Blévis, "L'invention de 1'indigène," 213-14; and Simon J. Rabinovitch, "The Quality of Being French versus the Quality of Being Jewish: Defining the Israelite in French Courts in Algeria and the Metropole," Law and History Review 36 (2018): 811-46. 
Enos admission, explaining that as a "native" (indigène), he was not entitled to the rights of a French citizen, a prerequisite for membership. The Imperial Court of Algiers upheld this decision, explaining that "natives" were not French citizens. Even so, the judges felt compelled to acknowledge that "everywhere in the world where he goes, a Muslim or Jewish native (indigène) need only invoke his quality of Frenchness (qualité de Français) to be immediately protected by the French flag." $" 73$ This amounted to an admission that Algerians were already attached to France, even if they lacked citizenship. In 1864, the Court of Cassation in Paris overturned the lower court's decision, ruling that Enos had the right to practice as a lawyer in Algeria. According to this court, Algerians were French nationals, even if they lacked full citizenship. This court, too, noted that Algerians were already considered to belong to France when abroad; in this ruling, however, the judges concluded that Algerians' status outside of Algeria was evidence that they must possess French nationality within Algeria. ${ }^{74}$ As a French national, Enos was eligible for admission to the Algerian bar. For our purposes, the case is significant because it offered the first instance of judicial confirmation that Algerians were French nationals.

The Sénatus-Consulte of July 14, 1865 enshrined the upshot of the Enos ruling in legislation: it declared that indigenous Algerians had the qualité de français - in other words, French nationality - but were not citizens. ${ }^{75}$ This legislation was partly a reaction to the Ottoman circular of 1863, which restricted the extension of consular protection to Ottoman subjects, the same circular that first attempted to regulate legal belonging 6 years before the Ottoman nationality law. The 1865 Sénatus-Consulte offered legislative clarification that Algerians in Ottoman territory were French nationals, not French protégés; they deserved extraterritorial privileges as French persons, a status that could be passed down to their children and was not hampered by the severe restrictions on the number of individuals who could hold a patent of protection (berat). Algerians were thus exempt from the Ottoman limitations on consular protection. ${ }^{76}$

73. Urban, L'indigène dans le droit colonial, 81.

74. Aylies, "Bâtonnier de l'ordre des avocats d'Alger v. Enos," in Jurisprudence générale ; recueil périodique et critique de jurisprudence, de législation, et de doctrine, ed. M. Dalloz (Paris: Bureau de la jurisprudence générale, 1864), 67-70; Blévis, "L'invention de 1' 'indigène," 213; Amara, "Être algérien en situation impériale," 81; Rabinovitch, "The Quality of Being French," 836-37.

75. Urban, L'indigène dans le droit colonial, 96-97.

76. Ibid., 74. The Sénatus-Consulte was also aimed at offering an easier path to naturalization for France's substantial population of non-French Europeans: Blévis, "Les avatars de la citoyenneté." 
Beyond France's empire, the distinction between someone with the qualité de français and a French citizen came to resonate in the vocabulary of legal belonging developing in Europe. As discussed, nationality was a new term in the early nineteenth century, and jurists were only beginning to work out its precise relationship to citizenship. When Cogordan published his monograph on nationality in 1879 , he insisted on a clear distinction between nationality and citizenship: "In general, a citizen is a national invested with full rights. One must not confound these two terms, as happens too often. Every national is not a citizen, although every citizen is a national. In France, for example, minors, married women, and exiles are not citizens, although they have French nationality; they have only civil rights and are deprived of political rights. Algerians do not even have civil rights; they follow Islamic law in private matters, and yet the Sénatus-Consulte of 1865 declared them French. ..."77 Cogordan presumed that all states made a distinction between those "invested with full rights" - that is, citizens - and those who belonged to the state but were "deprived of political rights," such as women, minors, and, in the French case, Algerians.

In the following decades, jurists came to evoke Cogordan's distinction between citizenship and nationality as a given. Today it is widely accepted by jurists and legal historians alike. ${ }^{78}$ Our understanding of the difference between nationality and citizenship is rooted in part in colonial Algeria. In sorting out the legal belonging of Algerians and their extraterritorial rights outside of Algeria, diplomats, politicians, and jurists eventually converged on a definition of nationality that would echo beyond the French Empire.

Unsurprisingly, the legislation decreeing that Algerians possessed French nationality hardly put a stop to controversies over their claims to extraterritorial privileges. Again, the case of Shamila illustrates the uncertainty that surrounded the legal belonging of those asserting Algerian origins. In the general absence of reliable documents - including passports, birth certificates, or any other written records-French consular officials

77. Cogordan, La nationalité, 6; on Cogordan, see Hajjat, Les frontières de l' 'identité nationale," 76. For an earlier precursor to Cogordan, see Johann Kasper Bluntschli, The Theory of the State (Kitchener: Batoche Books, 2000), 180-83.

78. European jurists only began to converge on a widely accepted distinction between citizenship and nationality at the turn of the century: Mira L. Siegelberg, Statelessness: A Modern History (Cambridge, MA: Harvard University Press, 2020), 31: see also André Weiss, Traité théorique et pratique de droit international privé : Tome premier, de la nationalité (Paris: L. Larose \& Forcel, éditeurs, 1892), 6-7, fn 2; Weis, Nationality and Statelessness, 3; and Koessler, "Subject, Citizen, National." For historians who make use of this distinction, see Hanley, Identifying with Nationality, 5-7; and Bronwen Manby, Citizenship in Africa: The Law of Belonging (London: Hart Publishing, 2018), ch. 1. 
relied on religious leaders to attest the identities of people claiming various forms of extraterritoriality. This was particularly important in cases in which simple facts of language or religion might not distinguish an individual with extraterritoriality from a local, at least in the eyes of Europeans. A native speaker might have been able to distinguish an Algerian dialect of Arabic from the one in the part of Tripolitania where Shamīla lived. But presumably neither Ottoman-speaking bureaucrats from Anatolia nor French diplomats could do so. Just like their Ottoman counterparts, French consuls regularly leaned on Jewish rabbis and Muslim notables to tell them who was really from Algeria. ${ }^{79}$ If anything, French officials felt they did not rely on religious authorities enough. In 1883, a French diplomat in Morocco wrote about the ease with which Moroccan Jews declared themselves to be Algerian and thus claimed extraterritorial rights as French citizens. He recommended that notaries writing up attestations of origin require that the "Jews called to testify should swear on the Torah Scroll before their rabbis. This formality will, I think, guarantee the sincerity of their declarations." ${ }^{80}$ By forcing Jewish witnesses to take an oath with religious significance, this official reasoned, they would be far less likely to falsify their testimony.

France's attitude toward extraterritorial privileges for its subjects abroad changed significantly as its empire expanded across North Africa. Before 1881, Algerians outside of Algeria had provided France with a convenient excuse to assert its influence in the Ottoman Empire and Morocco. But this changed once the French Empire expanded into other parts of North Africa; in the protectorates of Tunisia and Morocco, Algerians became a liability, rather than an asset. After France colonized Tunisia in 1881, colonial officials established two different legal systems; one for Europeans, and the other for native Tunisians. Whereas France classified Tunisian Jews and Muslims as "natives," Algerian Jews and Muslims were French nationals, and thus fell under the jurisdiction of Tunisia's French courts. Many French officials would have liked to place Algerian Jews

79. Noureddine Amara, "1830, l'improbable frontière : Les écritures précaires de la possession française d'Alger; Le Djérid à l'épreuve de la nationalité algérienne," in Penser le national au Maghreb et ailleurs, ed. Fatma Ben Slimane and Hichem Abdessamad (Tunis: Diraset-Etudes maghrébines, 2012), 92. See also the correspondence in the Archives de l'Alliance Israélite Universelle (AIU) (Paris, France), Tunisie I B 011 b, \#103-4, September 17, 1874, Elmilik to AIU President; November 3, 1876, AIU Committee in Tunis to AIU Central Committee. British authorities in Alexandria similarly relied on Catholic priests and rabbis to attest the origins of individuals claiming British protection: Hanley, Identifying with Nationality, 187.

80. Archives du Ministère des Affaires Etrangères (MAE), La Courneuve, France, CP Maroc 47, August 1, 1883, Monfraix to MAE. 
and Muslims under the jurisdiction of Tunisian judicial institutions, but their status as French nationals gave them a right to the jurisdiction of French courts. Nonetheless, even if French officials in Tunisia could not simply turn all Algerians into Tunisians overnight, they could make it harder to prove one's status as an Algerian. After 1881, French authorities were far stricter about admitting Jews and Muslims to the privileges associated with being an Algerian. For instance, Protectorate officials enforced the requirement that only Algerians who conserved an "esprit de retour" qualified as French nationals. All those who had settled permanently in Tunisia should be considered Tunisian. ${ }^{81}$ After the establishment of a French protectorate in Morocco in 1912, colonial authorities made similar attempts to avoid recognizing Algerian Jews and Muslims as French nationals. $^{82}$

The status of Algerians abroad - as entitled to French protection, and thus the extraterritorial privileges associated with foreign nationality-is crucial to understanding the development of legal belonging in the French Empire. The boundaries of legal belonging in France were not determined solely within the borders of French territory; legal belonging within colonial Algeria responded in part to the status of Algerians outside of Algeria. If we reinsert the imperial context into the history of nationality and citizenship in France, the extraterritorial Mediterranean emerges as central to the development of what it meant to belong to the French state. Extraterritoriality shaped the nature of legal belonging not only in the Ottoman Empire, Tunisia, and Morocco, but also in the French Empire.

\section{Conclusion}

Modern law governing legal belonging - usually called nationality lawis, on the surface, hyper-national. In fact, one might argue that all modern law is by definition national, as it originates with the state. ${ }^{83}$ And the laws regulating nationality and citizenship are, by definition, meant to be exclusionary. Nonetheless, examining the evolution of legal belonging in the Mediterranean suggests that the regulation of state membership did not emerge in nationally bounded siloes. Even laws defining the boundaries

81. Lewis, Divided Rule, 68-96.

82. Amara, "Être algérien en situation impériale," 65-66.

83. See, for example, Heather L. Ferguson, The Proper Order of Things: Language, Power, and Law in Ottoman Administrative Discourses (Stanford, CA: Stanford University Press, 2018), ch. 2; and Tamar Herzog, A Short History of European Law: The Last Two and a Half Millenia (Cambridge, MA: Harvard University Press, 2018), chs. 7-9. 
of belonging were formed in a multi-polity, multinational context. The entwined history of extraterritoriality and legal belonging suggests that it is possible to write a transregional history of nationality law. Such a global historical approach reflects the transnational nature of extraterritoriality itself: a projection of jurisdiction, and thus sovereignty, across territorial lines.

This Mediterranean-wide lens helps move beyond the centrifugal model of modernization that continues to influence scholarship. Modern regimes of legal belonging did not emerge fully formed in Europe, only to be imitated by Muslim polities some time later. Rather, the entanglement of extraterritoriality and legal belonging offers an example of how modern law was created in conversation across the supposed East/West divide. New approaches to legal belonging developed in the context of extraterritorial privileges, and thus across cultural, political, and jurisdictional lines. Putting Europe and the Islamic Mediterranean into a single analytic frame offers further ammunition against stereotypes of East versus West or traditional versus modern.

The case studies explored here are, of course, far from comprehensive; they are meant to demonstrate the benefits of a transregional approach to the legal history of both extraterritoriality and legal belonging. As such, they should be read as an invitation to pursue further research at both the micro and macro levels. Many questions remain outstanding: how did Ottoman, Tunisian, and Moroccan lower- and mid-level officials respond to the threat posed by increasing numbers of people with extraterritorial privileges? In other words, other than attempting to legislate legal belonging, in what ways did Middle Eastern polities respond to claims of extraterritoriality? Conversely, who were the individuals claiming foreign nationality and protection? How did their pursuit of extraterritorial privileges respond to the new regulations of legal belonging? While scholars have begun to answer these questions, there is much work left to be done. The study of legal belonging and extraterritoriality across the Mediterranean offers much promise, particularly for historians of law interested a globalized approach that transcends the boundaries within which legal history has traditionally been written. 